\title{
Credit to Women Entrepreneurs: The Curse of the Trustworthier Sex
}

\author{
Isabelle Agier and Ariane Szafarz*
}

This version: December 22, 2011

\begin{abstract}
Women entrepreneurs are known to receive smaller loans than men while repaying swifter. Does this evidence stem from business needs or from double-standard screening? To address this issue, we develop a new estimation method and apply it to an exceptionally exhaustive database from a Brazilian microfinance institution. The empirical results point to gender discrimination. We indeed show that women entrepreneurs receive smaller loans and incur lower losses for the lender. Additionally, we show that reducing the information asymmetry through lending relationship brings no remedy to the curse of the trustworthier sex.
\end{abstract}

Keywords: Small Business, Microcredit, Gender, Loan Size, Denial Rate, Default

JEL codes: G24, L26, O16, M13

*Isabelle Agier: UMR 201 - Développement et Sociétés (Paris I Sorbonne / IRD) and CERMi, Email: isabelleagier@gmail.com. Ariane Szafarz: Université Libre de Bruxelles (ULB), SBSEM, Centre Emile Bernheim, and CERMi, Email: aszafarz@ulb.ac.be. The authors thank Cécile Abramowicz, Juliano Assunção, Marie Brière, Marcella Corsi, Bert d'Espalier, Isabelle Guérin, Valentina Hartaska, Niels Hermes, Marek Hudon, Marc Labie, Anaïs Périlleux, Koen RosselCambier, Jean-Michel Servet, Rodrigo Soares, Øystein Strøm, Bruce Wydick, and the participants to the CERMi Research Day (Mons, October 2010) and the Second European Research Conference on Microfinance (Groningen, June 2011) for helpful discussions and suggestions. 
By focusing on poor female entrepreneurs in developing countries, microcredit has brought to light the underestimated potential of female self-employment. In particular, the microcredit industry has proved on a large scale that women are more trustworthy than men in terms of repayment (Beatriz Armendáriz and Jonathan Morduch, 2010). Nevertheless, Mayra Buvinic and Marguerite Berger (1990) and Diana Fletschner (2009) show that women are more credit-rationed than men $^{1}$ by microfinance institutions (MFIs). At first sight, the combination of women being more reliable and receiving smaller loans seems to indicate the presence of discriminatory loan allocation. However, men and women entrepreneurs differ in at least two respects: first, women are poorer than men on average, ${ }^{2}$ and second, the scope of their business projects is smaller.

In fact, assessing discrimination in lending is complex for reasons pertaining to both underlying economic theory and intrinsic econometric issues (Gary A. Dymski, 2006). In this paper, we define gender discrimination in lending as the economically unjustified awarding of inferior credit conditions to female borrowers. This narrow definition corresponds to the intuition of a double-standard lending practice, and is close in spirit to Becker's definition of "taste-based" discrimination (Gary S. Becker, 1971). It therefore excludes so-called "rational discrimination," where unequal credit conditions result from business needs.

Our empirical results point to gender discrimination. Indeed, all other things being equal, women face significantly worse credit conditions than men, while being creditworthier. Additionally, we show that reducing information asymmetry through relationship does not remedy the handicap of being female.

\section{Data and Methods}

Our unique database comes from VivaCred, a well-run Brazilian MFI. VivaCred provides credit to micro-entrepreneurs in low income communities and neighborhoods of Rio de Janeiro. It focuses on urban (formal and informal) microbusinesses such as storekeepers, craftspersons, and service providers. VivaCred charges the same interest rate to all its clients $\left(3.9 \%\right.$ per month) ${ }^{3}$ Its lending

\footnotetext{
${ }^{1}$ Credit rationing is to be understood here as lower loans granted to women, and not higher loan denial like in Joseph E. Stiglitz and Andrew Weiss (1981). This point is further discussed by Isabelle Agier and Ariane Szafarz (2010). Besides, in the context of microfinance, unfair credit rationing can be seen as a special case of mission drift (Roy Mersland and R. Øystein Strøm, 2010; Beatriz Armendáriz and Ariane Szafarz, 2011).

${ }^{2}$ According to the ILO (2009), $75 \%$ of worldwide poverty affects women.

${ }^{3}$ Banco da Mulher, a comparable non-profit institution, provides loans with rates between $3 \%$ and 5\% a month, while Fininvest, a for-profit institution, proposes consumer credit with a monthly $12 \%$ rate.
} 
methodology is thus based on credit rationing rather than on adjusting the interest rate to credit risk.

This study covers the eleven-year period 1997-2007 and is based on exhaustive data from 34,000 applications and 32,000 actual loans. Our dataset contains the full credit history of all borrowers. A repayment is considered defaulted after 180 days. The penalty for default is the client's name being added to the national register of bad payers.

In the microcredit framework, loan size is the sole credit condition that is tailored by the lender, whose problem may thus be represented as:

$$
\operatorname{Max}_{L S \geqslant 0}(1+r) L S-E[\operatorname{Loss}(L S)]
$$

where $r$ is the fixed interest rate, $L S$ is the loan size (denial corresponding to a zero loan size) that is the lender's decision variable, and $E[\operatorname{Loss}(L S)]$ is the expected loss that depends on loan size. Equivalently, this problem can be written:

$$
\operatorname{Min}_{L S \geqslant 0} \frac{E[\operatorname{Loss}(L S)]}{L S}
$$

On the empirical side, two variables are explained: the loan size (i.e., the decision variable), and the relative loss (i.e., the objective function): ${ }^{4}$

$$
\begin{aligned}
L S & =\beta_{F} F+\mathbf{x} \beta+\epsilon_{1} \\
\frac{L o s s}{L S} & =\varphi_{F} F+\mathbf{x} \varphi+\epsilon_{2}
\end{aligned}
$$

where $F$ is the dummy variable for the applicant's gender, $\mathbf{x}=\left(x_{1}, \ldots, x_{n}\right)$ denotes the applicant's other characteristics, and $\epsilon_{1}$ and $\epsilon_{2}$ are error terms.

Gender discrimination corresponds to the situation where $\beta_{F} \leq 0$ and $\varphi_{F} \leq 0$, with at least one strict inequality (Michael F. Ferguson and Stephen R. Peters, 1995). Moreover, the selection issue associated with loan allocation is addressed by using the Heckman estimation method (James J. Heckman, 1979).

\section{Findings}

Table 1 gives the mean values of the main variables split by the borrower's gender, with the significance of the t-tests for equality of means.

\footnotetext{
${ }^{4}$ Expectations being unobservable, we take realized loss as a proxy for expected loss. As loss is endogenous, the expectation error is absorbed in the error term of the regression without introducing any bias in the coefficients.
} 
VivaCred claims no special commitment to serve women. Its clientele is balanced, with 49.6\% of women over the period 1997-2007. Female borrowers request smaller loans (BRL 1,237 against BRL 1,518), ${ }^{5}$ and logically receive smaller amounts (BRL 891 against BRL 1,136). Nevertheless, men and women face similar approval rates, around 95\%. They also exhibit similar probabilities of default (2.9\%). Most importantly, women incur significantly smaller losses for the MFI, in both absolute and relative terms. VivaCred's average relative loss is $2.8 \%$ for male borrowers and $2.3 \%$ for female ones. These numbers are consistent with those reported by other MFIs. ${ }^{6}$

Table 1: Gender-Specific Mean Values

\begin{tabular}{lccc}
\hline Borrower's gender & Male & Female & t-test $^{\mathbf{a}}$ \\
\hline Requested amount & 1,518 & 1,237 & $* * *$ \\
Approval rate & 0.944 & 0.946 & \\
Loan size $^{\mathrm{b}}$ & 1,136 & 891 & $* * *$ \\
Loss $^{\mathrm{b}}$ & 20.18 & 14.63 & $* * *$ \\
Relative loss (X 100) & 2.756 & 2.286 & $* * *$ \\
Default rate & 0.030 & 0.027 & \\
\# previous loans & 2.356 & 2.157 & $* * *$ \\
Female guarantor & 0.429 & 0.430 & \\
\hline Observations & 16,899 & 16,631 & \\
\hline a t-test for differences between genders; *** significant at \\
$\quad$ the 1\% level. \\
b Amounts in deflated Brazilian Reais (BRL). Over the \\
period, the BRL fluctuated between 0.270 and 0.588 \\
USD.
\end{tabular}

Table 2 presents the regression results including one specification for loan size (equation (4), column (1) in the table) and three for relative loss (equation (4), columns (2)-(4) in the table). Column (2) displays the results for the basic formulation of equation (4) where the requested amount is included. In columns (3) and (4), the requested amount $(R A)$ is replaced by the loan size $(L S)$, and the rationing factor $\left(\frac{R A-L S}{R A}\right)$, respectively. The requested amount acts as a proxy for the entrepreneur's project size. In particular, it reflects the fact that women typically ask for smaller loans. By controlling for this rare piece of information, our aim is to clean the regressions of the effect of gender-specific requests. When

\footnotetext{
${ }^{5}$ The average requested amount for all applications, including denied ones, is BRL 1,250 for women and BRL 1,524 for men.

${ }^{6}$ For instance, reported default rates are: below 2.2\% for CrediAmigo in Northeast Brazil (CrediAmigo, 2009), below 5\% for the Grameen Bank in Bangladesh (Jonathan Morduch, 1999), and between 1 and 5.5\% for rural MFIs in Indonesia, with a single exception of $12 \%$ (Marguerite S. Robinson, 2002).
} 
Table 2: Loan Size and Relative Loss: Heckman's Regressions

\begin{tabular}{lcccc}
\hline & $(1)$ & $(2)$ & $(3)$ & $(4)$ \\
& LS & Loss/LS & Loss/LS & Loss/LS \\
\hline Female borrower $(\mathrm{F})$ & $-26.46^{* * *}$ & $-0.741^{* * *}$ & $-0.774 * *$ & $-0.819^{* * *}$ \\
& $(6.572)$ & $(0.220)$ & $(0.220)$ & $(0.219)$ \\
\# previous loans & $38.62^{* * *}$ & $-0.295^{* * *}$ & $-0.255^{* * *}$ & $-0.241^{* * *}$ \\
& $(1.301)$ & $(0.0434)$ & $(0.0442)$ & $(0.0429)$ \\
\# previous loans * F & $-2.901 *$ & -0.00980 & -0.0115 & 0.00218 \\
& $(1.695)$ & $(0.0566)$ & $(0.0567)$ & $(0.0563)$ \\
\hline Requested amount & $0.632 * * *$ & $-1.83 \mathrm{e}-05$ & & \\
& $(0.00281)$ & $(9.37 \mathrm{e}-05)$ & & \\
Loan size & & & $-0.000481 * * *$ & \\
& & & $(0.000119)$ & \\
Rationing factor & & & & $0.0424 * * *$ \\
& & & & $-0.00394)$ \\
\hline Female guarantor & $-31.54 * * *$ & -0.237 & -0.295 & $(0.187)$ \\
\hline Wald Chi2 & $(5.637)$ & $(0.188)$ & $(0.189)$ & 875.7 \\
\hline
\end{tabular}

Controls: Client: married, at least one dependant, age, external income, number of previous loans with delay, number of previous experiences as guarantor; Business: profits, sector (trade $=1$ ), formal, number of employees; Loan: capital investment, loan repayment purpose, no guarantor, female loan officer, year dummies. Standard errors in parentheses; *** $\mathrm{p}<0.01, * \mathrm{p}<0.1$.

Heckman selection: Having received at least one loan; $\mathrm{N}=30,851$, Censored obs.: 1,792; Selection instruments: kind of premises, source of funds, loan officer's family status, seniority, favela resident, loan officer turnover experienced by the client, Rocinha branch.

including loan size, ${ }^{7}$ we control for the level of indebtedness irrespectively of the source of the gender gap.

The motivation for proposing these three specifications for equation (4) is the following. The correlation between the requested amount and the loan size is high (0.667). For this reason, we avoid putting both variables simultaneously in the second regression. Instead, we opt for a third specification using the rationing factor measuring the fraction of the requested amount that has actually been granted to the applicant.

The regressions bring enlightening results. Indeed, column (1) in Table 2 confirms that women suffer from harsher credit rationing than men. Indeed, even

\footnotetext{
${ }^{7}$ The inclusion of loan size in the second equation is tricky because it is the dependent variable of the first equation. In reality, though, the inclusion has little effect on the coefficient of the gender dummy.
} 
when accounting for the selection bias and the differences in requested amounts, women receive significantly smaller loans than men. Moreover, in all specifications the gender dummy has a significant negative impact on relative loss, meaning that, all things equal, women are creditworthier than men. The requested amount in itself has no significant impact (column (2)).

Additionally, the loan size affects relative loss negatively while the rationing factor has a positive impact. Loans that are more tightly rationed are harder to repay. Remarkably, despite the handicap of being more credit-rationed, women manage to reimburse their loans better than men. In other words, if men and women were equally rationed, female repayment conduct would be even better than it actually is.

The regressions in Table 2 also make it possible to examine the impact of relationship lending on the gender gap in loan size. Our database includes 11,422 different borrowers, among which $63.31 \%$ benefited from a second loan. About one third of the newcomers dropped out after their first loan. As expected, the number of previous loans has a positive impact on loan size and a negative impact on relative loss. More troubling is the negative effect of the interaction term on loan size. ${ }^{8}$ While men benefit from an average extra BRL 39.57 for each previous loan, women see this bonus in loan size reduced by BRL 4.95, thus amounting to BRL 34.62 only. Relationship lending seems thus less valued for females, widening the gender gap instead of narrowing it.

Globally, the results are robust. The coefficient of the gender dummy is about the same in all three specifications of the relative loss equation. Moreover, the coefficient of the guarantor's gender reveals that female guarantors have a negative impact on loan size compared with male guarantors, but no significant impact on relative loss. This can be viewed as an additional stigma of gender discrimination, albeit in a milder form. Regarding the methodology, although the legitimacy of using Heckman's regressions is testified by a significant Mills ratio, we checked that ordinary-least-square regressions have similar features (results not reported here).

Lastly, the regressions use all the screening variables collected by the MFI itself. Nevertheless, we cannot rule out that face-to-face interviews bring unobservable but relevant gender-related information, linked for instance to education, financial literacy, and attitude toward risk (Suresh de Mel, David McKenzie and Christopher Woodruff, 2009). Moreover, we do not have information on the steps that predate the formal loan application. For instance, an informal contact with a loan officer might discourage some entrepreneurs from pursuing the application process. However, it seems unlikely that such unobservable elements could challenge the conclusion pointing to discrimination. More plausibly, they would

\footnotetext{
${ }^{8}$ The coefficient is significantly negative at the 10 percent level only.
} 
reinforce it.

\section{Conclusion}

In a nutshell, we show that, all things equal, women entrepreneurs receive smaller loans and incur lower losses for the lender. This result is consistent with the stylized facts reported by Armendáriz and Morduch (2010). Nonetheless, our findings are more reliable than rough descriptive statistics since the regressions take into account all the variables actually reported by loan officers, including the required amount.

Furthermore, the gender gap in loan size increases with relationship lending and subsequent informational asymmetry dwindling. Although more trustworthy than men, women entrepreneurs seem to be eternally cursed. Starting with smaller first loans than men, they never overcome from their initial handicap. This finding argues strongly for external intervention to combat gender discrimination.

As a matter of fact, the microcredit industry is highly subsidized internationally (Marek Hudon and Daniel Traca, 2011) notably by donors having a women empowerment agenda. Given the lack of anti-discrimination regulations in many developing countries, donors' concern could be seen as an alternative disciplining device. However, data unavailability is a main obstacle implementing antidiscrimination awareness. The first thing donors should do, therefore, is to request more transparency in the screening processes.

Our findings raise additional unanswered questions. Firstly, why are women entrepreneurs more trustworthy than their male counterparts? Do they fear penalties more, a hypothesis compatible with the evidence that women are more riskaverse than men (Lex Borghans, Bart Golsteyn, James J. Heckman and Huub Meijers, 2009)? Secondly, why do women ask for smaller loans? Do they expect to be discriminated against and refrain from applying for riskier projects, thereby creating a self-selection effect? Lastly, how do women manage to reimburse better than men while being more credit-rationed, and how do household constraints interfere with female business projects? Recent studies on intra-household relations in India (Supriya Garikipati, 2008) show that access to credit may increase female financial vulnerability.

These issues need to be addressed seriously, at the very least for economic reasons. Indeed, the potential for female-driven economic development is far from being exhausted. Better knowledge of the needs and aspirations of women entrepreneurs will help with the design of gender-conscious financial products, as emphasized for the microfinance industry by Susan Johnson (2004), Isabelle Guérin (2011) and many others.

By demonstrating that even well-run socially-oriented MFIs are not immune 
to gender discrimination, this paper has stressed the importance of finding creative solutions to lack of capital that women entrepreneurs endure.

\section{References}

Agier, Isabelle, and Ariane Szafarz. 2010. "Microfinance and Gender: Is There a Glass Ceiling in Loan Size?" Université Libre de Bruxelles CEB Working Papers 10-047.

Armendáriz, Beatriz, and Ariane Szafarz. 2011. "On Mission Drift In Microfinance Institutions." In The Handbook of Microfinance, 341-366. LondonSingapore, B. Armendariz and M. Labie (Eds):World Scientific Publishing.

Armendáriz, Beatriz, and Jonathan Morduch. 2010. The Economics of Microfinance. 2 ed. Cambridge, MA:The MIT Press.

Becker, Gary S. 1971. The Economics of Discrimination. 2nd ed. Chicago, IL:University of Chicago Press.

Borghans, Lex, Bart Golsteyn, James J. Heckman, and Huub Meijers. 2009. "Gender Differences in Risk Aversion and Ambiguity Aversion." IZA Discussion Paper 3985.

Buvinic, Mayra, and Marguerite Berger. 1990. "Sex Differences in Access to a Small Enterprise Development Fund in Peru." World Development, 18(5): 695705.

CrediAmigo. 2009. “CrediAmigo Annual Report - 2009.” www.bnb.gov.br.

de Mel, Suresh, David McKenzie, and Christopher Woodruff. 2009. "Are Women More Credit Constrained? Experimental Evidence on Gender and Microenterprise Returns." American Economic Journal: Applied Economics, 1(3): 1-32.

Dymski, Gary A. 2006. "Discrimination in the Credit and Housing Markets: Findings and Challenges." In Handbook on the Economics of Discrimination, W.M. Rodgers III ed., 215-259. Cheltenham:Edward Elgar Publishing.

Ferguson, Michael F., and Stephen R. Peters. 1995. "What Constitutes Evidence of Discrimination in Lending?" Journal of Finance, 50(2): 739-748.

Fletschner, Diana. 2009. "Rural Women's Access to Credit: Market Imperfections and Intrahousehold Dynamics." World Development, 37(3): 618-631. 
Garikipati, Supriya. 2008. "The Impact of Lending to Women on Household Vulnerability and Women's Empowerment: Evidence from India." World Development, 36(12): 2620-2642.

Guérin, Isabelle. 2011. "The Gender of Finance and Lessons for Microfinance." In The Handbook of Microfinance, 589-612. London-Singapore, B. Armendariz and M. Labie (Eds):World Scientific Publishing.

Heckman, James J. 1979. "Sample Selection Bias as a Specification Error." Econometrica, 47(1): 153-61.

Hudon, Marek, and Daniel Traca. 2011. "On the Efficiency Effects of Subsidies in Microfinance: An Empirical Inquiry." World Development, 39(6): 966-973.

ILO. 2009. "Small Change, Big Changes: Women and Microfinance." International Labour Organization, Geneva.

Johnson, Susan. 2004. "Gender Norms in Financial Markets: Evidence from Kenya.” World Development, 32(8): 1355-1374.

Mersland, Roy, and R. Øystein Strøm. 2010. "Microfinance Mission Drift?" World Development, 38(1): 28-36.

Morduch, Jonathan. 1999. “The Microfinance Promise.” Journal of Economic Literature, 37(4): 1569-1614.

Robinson, Marguerite S. 2002. Microfinance Revolution Volume 2: Lessons from Indonesia. World Bank Publications.

Stiglitz, Joseph E., and Andrew Weiss. 1981. "Credit Rationing in Markets with Imperfect Information.” American Economic Review, 71(3): 393-410. 